\title{
The War: the Facades Collapse
}

\author{
Tatiana Gnedovskaya \\ State Institute for Art Studies \\ Moscow, Russia \\ E-mail: tgnedovskaya@gmail.com
}

\begin{abstract}
The global processes in German architecture of the first quarter of $\mathrm{XX}$ century are studied. The origins for the style changes in this historically short time stretch are analyzed. A special appention is paid to the role of the First World War.
\end{abstract}

Keywords-architecture; style; historicism; moderne; neoClassicism; expressionism; First World War

\section{INTRODUCTION}

When the German Empire entered the First World War, it was at the peak of its industrial and art development. After the end of the economic crisis in the mid-1890s, the young ambitious state headed from 1888 by a no less young and ambitious monarch saw vigorous industrial growth and simultaneously a global reform in applied arts and architecture.

\section{FROM HistORICISM TO NEW STYLE}

The new universal art style, which the Kaiser's enthusiastic peers aspired to create at the turn of the $20^{\text {th }}$ century, was in large measure formed "a contrario" as an alternative to eclecticism that was referred to as historicism in some countries. "Nowadays fashion has replaced style" [1], wrote the Belgian artist Henry van de Velde, who had moved to Germany in the early $20^{\text {th }}$ century. The German architect Hermann Muthesius, another reform ideologist, claimed that the period of dominant eclecticism in the applied arts and architecture became for Germany "a time of complete loss of taste and sense of style" [2].

One of the key claims the advocates of reforms laid against historicism was its "falsity", meaning not only the imitation of various "styles" and a tendency toward inordinate ornamentation. $H$. Walden complained that contemporary architects "seem to have no other cares but to decorate houses" [3]. Eclecticism was blamed for a far greater evil, namely, for ruining the basic and until then unbreakable connection between the functional filling of the house, its spatial layout and exterior.

A directly opposite design principle of "inside-out" got the upper hand in the period of Style Moderne, which replaced historicism. Henry van de Velde is thought to have been among the first to formulate it when designing his own house in Uccle in 1895. Incidentally, for many artists who gradually qualified as designers it was precisely their own studio homes that became their first architectural projects. For that matter in general the individual residential mansion emerged as the central style-forming type of building at the turn of the $20^{\text {th }}$ century. In part, this was because the individual personality came to the centre of attention at that time, and a new type of residence was to account for its image. In addition, it was the residential mansion that gave designers the coveted chance to create from scratch without conforming to the surrounding development and doing without proper façades: an architectural structure was to parallel a huge sculpture to be viewed from all sides. Frequently, such houses lost not only the usual appearance, but also the traditional linear-axial layout because the premises spiraled, as it were, around the central hall or the stairway.

\section{THE EPOCH OF “OVERSIMPLIFICATION AND RATIONALIZATION"}

Expansion and the changing goals faced by the founders of the New Style soon made them realise that the inordinately individualized and aestheticized approach of the Style Moderne was impracticable. As early as 1905, Peter Behrens declared that "true art is made by creative personalities who have their feet on the ground and a sober view of their artistic aspirations" [4]. That pronouncement reflected the sentiments of that period perfectly well. Its universality is not cancelled by the fact that it was made at the opening of an alcohol-free restaurant: the spread of temperance societies in Germany was another symptomatic phenomenon of the time.

The epoch of "oversimplification and rationalisation" started around 1905-7. The pretentions of the Style Moderne and its mystical overtones, as well as the artists' gravitation to specific ecstasy and trance were now rejected. A new art was to embark on the road of functional logic and simplicity, consequently simple, universal and hierarchically well-tested principles of planning and decorating façades grew increasingly in demand.

The contemporaneous mutual attraction between artists and industrialists and their shared desire to see a fundamentally new art - mass and yet top quality - found expression in the organisation of the Deutscher Werkbund (German Association of Craftsmen) in 1907. Interestingly, the Deutscher Werkbund formed in the year, which many historians refer to as the turning point toward historicism. I believe that this coincidence was not fortuitous. The artists' want of an association, of having an organised social structure was a phenomenon of the same 
order as their striving after a uniform "objective" principle in art.

\section{NEO-ClASSICISM AS A COMPROMISE}

In full conformity with that striving the appearance of architecture built in Germany around 1907-8 tended toward growing uniformity. The increasing introduction of neoclassicist decorative elements and structural principles in architecture brought about the long-awaited stylistic commonality. The overwhelming majority of architects and critics were unlikely to register those imperceptible changes, to say nothing of worrying about them. However, the sensitive Henry van de Velde sounded alarm already in 1907, "I fear very much that the appeal of Biedermeier and neoBiedermeier to the public and a certain circle of artists is explained primarily by universal weariness. $\langle\ldots\rangle$ Yet, reversal to Biedermeier is a compromise that, no doubt, threatens the development of the new style" [5]. Interestingly, Nikolay Berdyaev wrote in a similar vein in the same period: "Weariness of Nietzsche is felt in the spiritual life of Germany, they have decided there to take a break from Nietzschean catastrophicity and extremity and gravitate toward Goethe, toward calm harmony, pantheistic reconciliation with nature, toward high culture without imminent cataclysm" [6]. The terms used in the above quotations show that Berdyaev impartially stated the fact of German culture reverting back toward classicism while van de Velde was indignant and for this reason described the new tendencies most disparagingly (from his point of view) as Biedermeier, that is, classicism in its latest, mass-scale and "base" variety.

Far from all the architects, critics and art historians of Germany reacted to the development just as painfully as van de Velde did. Suffice it to name P. Schultze-Naumburg, P. Mebes or F. Ostendorf, who consistently promoted "the architecture of the 1800 s". With every passing year ever more clients and designers paid heed to their arguments. Classicism had long been associated with dignity, peace and harmony. It guaranteed cultural and psychological continuity as, Walther Rathenau wrote, "classicist art has become in our perception a constituent of humanised, yet pristine Nature, as it were, and blended into our life no less than ploughed land, a garden flower or cultured fruit" [7].

The natural evolution of architecture, too, led to neoClassicism. How else can we explain the fact that at a certain stage the impact of the classical tradition was even felt in the work of Henry van de Velde himself? Osthaus wrote about the Ernst Abbe memorial van de Velde built in Jena as early as 1908: "the outside appearance of this building demonstrates convincingly the artist's dialogue with Antiquity" [8]. The same is true of his designs for the Weimar Neues Museum (1907), the Théâtre des ChampsÉlysées (1911) and the Nietzsche monument in Weimar (1911-2). Another indisputable leader of the artistic process, Peter Behrens, unexpectedly confessed in the 1910s that he did not regard Schinkel as his creative predecessor and "did not see Morris, Burne-Jones, etc, and what he called 'the similar German romantics' as the pioneers oft he modern movement in architecture and design, but rather the nineteenth-century Neo-Classicists" [9].

What Behrens said proves that even the most bright and original architects of that period took interest in historical and artistic heritage. It is easy to surmise that the very rationalization process led them to classicism. The simpler, more clear-cut and, consequently, standard the building layout became, the more it gravitated to well-defined planning, zoning and symmetry axes. Individualistically spontaneous creativity gave way to stable order and hierarchy, the two crucially fundamental qualities of classical architecture.

Of no small importance in that reversal to neo-Classicism was the gradually expanding field of vision and application of reformer architects, most of whom started as easel artists. In their career nearly all of them proceeded from "things small" to "things large" and for this reason at a certain stage ensembles, settlements and later entire cities were at the centre of their attention rather than interiors or individual houses. An open competition was organised in 1910 for the renovation of the so-called Greater Berlin. Most of the architects opted for neo-Classicism as the style of a modern metropolis. In addition to ensuring the mimicry of new structures in the historically established environment, it also gave the designer a universal clue to solving general and specific problems.

\section{NEO-CLASSICISM AND GLOBAL POLITICS}

A programmatic article Hermann Muthesius published in 1911 served to substantiate theoretically the processes discreetly taking place in German architecture. According to Muthesius, the attitude to "form" had to be resolutely revised. During the rationalisation period an aesthetically consummate form was thought to be a natural and immutable result of the artist's observing the expediency principles. Now Muthesius resolutely reversed cause and effect and asserted that "the spiritual is far more important than the material and form is above practical objective, material and technology" [10].

The close attention to "form" paid in that article by the chief ideologist of Werkbund marked a crucial turning point in views and precepts. "External", "formal" and "façade" considerations again had the upper hand over those of "substance", that is, functional and technological. Muthesius suggested that architecture be re-assigned to the level of the principal style-forming art, to which all the rest should be subordinate as secondary. Now the "city" was to dictate its aesthetics to the "house", the "house" to equipment and so on, that is, style was to spread from the larger to the smaller and not the other way round. Correspondingly, the earlier "inside out" design principle also changed to the opposite "outside-in".

Muthesius now took an entirely new look at the relationship between art and industry. Formerly, the image of mechanisms and their expedient structure inspired artists to look for a new style, whereas now Muthesius wanted artists to emulate the very principle of industrial production rather than machinery aesthetics. Muthesius believed that at the 
current stage applied arts and architecture "gravitate toward subordination to one guiding idea, toward the arrangement of the particulars in strict order with respect to the whole, and toward neglect of secondary features in favour of the more essential ones" [11]. Individual ideas should join the general mainstream and become subordinate to directives. Only in this way will German applied art be able to shed diffidence and become a full-fledged constituent of the national economy. Only in this way will it be able to make the needed profit and win competition on the international market. To organise the entire artistic process in accordance with the "modern factory" principle, art itself will have to have predictable, that is, standardised forms.

These tendencies in national art life were fully in tune with the public sentiments and the aspirations of the authorities. As is known, Wilhelm II dreamed of transforming the country into a sort of analogue of an ideally organized military camp. Already in the beginning of the $20^{\text {th }}$ century the idea of perfect order became fused in the German public mind with the idea of national grandeur. Politicians, economists, entrepreneurs and even people of art spoke ever more loudly and frequently about the need to spread that order not only to all spheres of life inside the country, but also outside it. Nationalism not merely gathered momentum in the country, but acquired tougher organized forms. Spontaneous patriotism that had opened up new horizons for the German residents at the turn of the $20^{\text {th }}$ century was now increasingly harnessed by the government policy and exploited by it. Alexander Benois, who travelled across Germany in 1910, wrote: "Where has all German Gutmütigkeit got to? [12] In the past the prevalent view was that the formalist Prussians were in the north, but next to them were the cosy Saxons and below 'the absolutely good old' Bavarians. Now everywhere there lives the same breed of hurrying bustling people, the stupefied slaves of their own Pflichtgefühl [13], annoyed, impudent and smug at that. They are nation No. 1 in the world, they are the winners and conquerors" [14]. The over-exaggerated importance of national history led to stronger retrospective tendencies in art. The evaluation criteria changed imperceptibly, with ideological rather than aesthetical considerations moving to the fore.

The concepts of the ideal and hierarchically well-tested order, as well as of "great German history" were visually embodied in monumental neo-Classicist buildings that kept cropping up in different German cities. The "threedimensional" Style Moderne gave way again to definitely ceremonial "façade" architecture.

Of course, there was a world of difference between the once abandoned eclectic façades and the neo-Classicist façades eventually arrived at. The compositions and patterns of eclectic façades were far more arbitrary. Not infrequently, they looked like a carpet that could be extended left, right and upward. The neo-Classicist façades, as a rule, had more clear-cut symmetry axes and an overall hierarchically tested consummate composition. However, with the passage of time that difference was increasingly obliterated as the prewar neo-Classicism acquired eclectic features and became segmented, small-scale and superfluous. From the later version of eclecticism neo-Classicism inherited yet another malaise, gigantomania.

The huge structures decorated with boundless colonnades, which appeared before the war, provided graphic evidence that the striving after order had increasingly degenerated into attempts to produce its appearance. That tendency was obvious in almost every sphere of prewar German life: the more all-embracing and consistent was the desire to streamline all and everything, the more formal and fictitious were its results. However, it was in architecture that that substitution became especially conspicuous. The striving after consistency and logic, which had led the architects to neo-Classicism, seemed to have transformed into its opposite at the subsequent stage of the development of the style. When neo-Classicism finally prevailed over all the other trends, it revealed a truly amazing propensity to overcapacity. E.I. Kirichenko writes about a similar process in prewar Russian architecture: "In interiors - in official interiors - in columns faced with imitation marble, the columned lobbies and tenement building flats, as well as in the mansion suite of rooms there is an aggregation of artistic means, outbursts and deliberateness absolutely alien to classicist compositions that come to life easily and naturally" [15]. She notes the tendency toward deliberate theatricality, which was characteristic of prewar European retrospectivism: "Suites of grand halls, front stairways, porticos and columned halls aren't they all the theatricalisation of the interiors, theatricalisation that has nothing to do with the utilitarian aspect of construction from the point of view of real material and structures and that served the most theatricalised part of life - the representative one?" [16] Readiness to sacrifice inner order for the sake of outer order was especially manifest in the buildings of the Werkbund exhibition of 1914 in Cologne. It was the first major comprehensive display of the organisation's accomplishments, on which the contributors and outside observers sympathising with the reforms pinned great hopes. Alas, most of the pavilions, executed in some mean average neo-Classicist vein, illustrated the sad metamorphosis of German architecture in the five years before the war.

As the wise Robert Musil wrote "Order somehow turns into the need for manslaughter". The striving after the utmost spread of the ideal "German order", which found expression, among other things, in neo-Classicist buildings, provoked expansion. It seemed that the victories and accomplishments of the Germans inside the country simply obliged them to extend their successful experience beyond its borders. "Hardly any other country, apart from the faraway America, saw industry develop so successfully as Germany of the time of Wilhelm. Inasmuch as it provided the means, it forced the nation to pursue an expansionist imperialist world policy. $<\ldots>$ Until then Germany was a European power, now it wanted to become a world power" [17]. Friedrich Naumann, one of the ideologists of the Werkbund, announced at its 1914 Congress that the following stage in the life of the organisation should be called "Werkbund and the World Economy" [18]. 


\section{THE WAR AS A TURNING POINT}

The enthusiasm, with which the Germans entered the First World War, is known to have reached extraordinary heights in the beginning, but it was short-lived. The young architect Walter Gropius, a disciple of Behrens's, wrote from the frontline that he "thinks he finally understands what they mean when they charge us with 'militarism' and why everybody hates us so much. The German state has become the end in itself. The individual exists for the state rather than the state for the individual" [19].

The war showed that all hopes for the ideal order, for thinking moves ahead and predicting their consequences were a dangerous illusion. As a result of the war crumbled not merely the house façades, but also the positivist tenets, which were embodied in them and which were so widespread in prewar Germany. What had been hidden behind those fine-looking "life façades" now lay bare - the sick, cruel and simultaneously helpless innards of the world, the seamy side of human life, ugliness, humiliation and death.

Small wonder that after the end of the war "the bearers and opponents of the state reversed their positions. The former bearers of the Kaiser Empire now found themselves in the opposition while the former opposition was now the bulwark of the republic" [20]. The same shake-up took place in the German artistic community. The young, who had returned from the front, took up the initiative and revised the basic tenets. Thomas Mann wrote that after the war "A new mental attitude was proclaimed for all mankind, which should have nothing to do with bourgeois principles such as freedom, justice, culture, optimism, faith in progress, As art, it gave vent to expressionistic shrieks from the soul; as philosophy, it repudiated the reason and the mechanistic and ideological conceptions of bygone decades; it expressed itself as an irrational throwback, placing the conception life at the center of thought, and raised on its standard the powers of the unconscious, the dynamic, the darkly creative, which alone were life-giving" [21].

\section{ARCHITECTS AND EXPRESSIONISTS: DREAMS AND REALITY}

Bruno Taut, Walter Gropius and their elder colleague Hans Poelzig, who called for repentance, purification and self-exposure, found themselves among the architecture leaders of that period. "It was impossible to go back to any of the traditions of the period, in which we willy-nilly thought all the misfortunes originated. Everything which was done then seemed in one way or another to be connected with the origins of war", [22] Bruno Taut recalled. And here is what Gropius had to say about it: "After that violent eruption, every thinking man felt the necessity for an intellectual change of front" [23].

In his article "Kritik des Werkbundes", published in the Sozialistische Monatsheften newspaper, Adolf Behne wrote: "Nobody is going to deny the Werkbund's pure and lofty aspirations, but with the passage of time it is becoming increasingly clear that, to really serve German art, a different road should be chosen. $\langle\ldots\rangle$ Art is an autonomous field that can follow or serve nothing else. Only when we start again feeling reverence to art, make it absolutely free from all commitments and release it from educational, economic or technical obligations, will it be able to attain genuine heights, giving us happiness and beauty" [24].

The renewed striving after the "particular" and "honesty" in architecture found expression in the abandonment of what had previously been meant to perform the representative function and create the outward impression of harmony - the grand neo-Classicist façades. In general, Order architecture gave way to organic architecture in the works of those who sought a way out of the aesthetical and ethical impasse. The usual tectonics was rejected in favour of buildings looking like gigantic anthills, bird-nests or stalactite caves.

Still another new tendency was the worship of glass as construction material of the future. An informal Glass Chain correspondence was launched in 1919, involving 12 members who exchanged open manifesto letters and drawings. The call to build houses with transparent walls virtually embodied the striving after self-exposure and explicitly pacifist pathos. After terrible war destruction the most vulnerable and brittle of all possible materials was proposed as the prevalent material of modern times.

Two structures of the 1914 Cologne exhibition, which offered a scant alternative to the numerous neo-Classicist buildings, sparked fascination with ideas for glass architecture. They were the Glass Pavilion of Bruno Taut and the model factory of Walter Gropius. The concepts of the two pavilions formed the basis of two fundamentally different interpretations of glass in postwar construction.

The early postwar period saw the wide spread of the ideas of Paul Scheerbart, a German mystic philosopher and author of fantastic literature, the ideas developed in literary and architectural works by his younger friend and disciple Bruno Taut. Already in his Cologne Glass Pavilion, designed in collaboration with Scheerbart, Taut sought to translate into life Scheerbart's theosophical theories about attaining a mystical connection between the human individual and cosmos through architecture. As the war had called into question the credibility of the idea of serving the state and rationally organised society, such ideas proved quite popular in the artistic community of the early postwar years. "We are after the innermost transformation of entire art so that the current artistic chaos become artistic cosmos", [25] declared critic Adolf Behne, a friend of Taut and Glass Chain contributor.

Scheerbart died in 1915. Meanwhile, Taut was in the prime of his creative career in the last years of the war and the early postwar period, emerging as a leading ideologist and herald of change: "Death to everything called title, dignity, authority! Down with everything serious! <..> Hurray, three times hurray for our kingdom without force. Hurray for the transparent, the clear! Hurray for purity! Hurray for crystal! Hurray and again hurray for the fluid, the graceful, the angular, the sparkling, the flashing, the light hurray for everlasting architecture!" [26] Taut calls glass structures "everlasting" because time is powerless against glass, which defies the process of aging and gradual organic decomposition. However, Taut completely disregards the 
fact that a shock-wave, to say nothing of a direct shell hit, is capable of breaking glass: a happy future has no use for wars!

Anyhow, the architect does take into account the past war experience. Like many in those years, he advocates resettlement from metropolises that proved highly vulnerable during military operations to the countryside. Nature was to become a source of comfort and harmony and a place where mankind should build crystal settlements pervaded with light and colour and growing in all directions like organic formations, gigantic flowers, lichen or mycelium. No strict order, no geometry, no façades. Again, as in the time of the Style Moderne, new buildings should come up as greenfield projects, forming a part of Nature rather than the city.

Walter Benjamin wrote, “...glass is such a hard, smooth material to which nothing can be fixed. A cold and sober material into the bargain. Objects made of glass have no 'aura'. Glass is, in general, the enemy of secrets" [27]. The architectural ideas about the construction of glass towns, which Taut expounded in his open letters, articles and books, including Alpine Architecture, The Dissolution of Cities and The City Crown, gave the lie to the above pronouncement. According to Taut, glass was to capture, preserve and show man the mysteries of the universe and his own soul. His was not so much glass as crystal architecture refracting light or any other beams in unpredictable ways. It was meditation architecture that not only opened man and his soul up to the surrounding nature and cosmos, but also concealed and protected him from the bustling and at the same time strictly regulated "flat" world of human beings.

Walter Gropius based his glass structures on entirely different principles. Already before the war the glass buildings of the Fagus Werk and the Model Factory of the 1914 Werkbund exhibition in Cologne had been built to his designs. Unlike Taut, Gropius equated concepts such as glass and truth, glass and reality in those works of his. According to him, glass symbolized the individual's coming together not only with nature but also with socium. Such an approach proved popular at the following stage of the development of German architecture, when expressionism was replaced by the epoch of "new objectness" and enthusiasm about the rationalist ideas.

Before the war Gropius deemed it possible and even necessary to reveal to the world the hitherto bashfully concealed "factory innards" because he was among the first to see the industrial process as a new standard of beauty. In the era of rationalism, which started around 1923, he and his rationalist comrades set themselves the task of making the process of daily human existence as open and observable as possible. An end had to be put to the prewar world, in which everything controversial and adverse had been hushed up, kept secret and hidden behind respectable architectural sets. The pompous and impenetrable stone façades were to be replaced with invisible stone walls, merging the inner and the outer world into a single whole. The rationalist architects were inspired by the ambition to be able to organise and finetune the ordinary life of rank-and-file citizens of their land so that it should parallel, as it were, the industrial process and thus become an aesthetically full-value spectacle.
In parallel, it was hoped that the harmonious man of the future would not stick to property and no longer need seclusion. Man's home was eventually to cease being his castle. Gropius was convinced that most people would prefer comfortable and impersonal hotel rooms to houses and flats in the near future. Ludwig Hilberseimer suggested that the private space of a private flat should be restricted to a bedroom of minimum size with a bathroom and toilet while all the other life cycles, according to him, should take place in public in communal kitchens, laundries, canteens and clubs.

This idea of being open to society went hand in hand with the idea of openness to Nature - the sun, the sky and the wind. The flat roofs, which became the rationalists' trademark, were known to serve, among other things, for physical exercises and sunbathing. This divesting houses of walls and roofs in the usual sense of the words was paralleled by the "exposure" of the people, whose clothes became ever more functional and revealing the body: personal chastity was declared just as archaic and inappropriate in the contemporary circumstances as personal or family privacy.

\section{CONCLUSION}

Around 1926-7 it became clear that the conservative majority of the German population did not welcome all those tendencies. Once again nationalist and revanchist ideas replaced those of repentance, humility, self-exposure, global brotherhood and pacifism. Along with calls for a return to cultural and ethical traditions, the grand neo-Classicist construction projects, with the invariable monumental façades, started going up in different cities. That tendency is known to have climaxed in the Third Reich period, when an attempt was made on an unprecedented scale to recruit architecture to build a complex of monumental sets for the virtual being which Nazi propaganda insisted on being the reality.

I want to close with a quotation from the directive that Friedrich Tamms, a Third Reich architectural ideologist, published in 1942 under the title Grosse in der Baukunst (Greatness in Architecture). He wrote that Third Reich architecture must be "strict, sparing, clear-cut and executed in classical forms. It must be simple. It must have within it the measure 'of what touches the heavens'. It must go beyond human scale. It should be executed with amplitude, solidly put together, and built according to the most established rules of the trade, as if it were for eternity. It must in the practical sense, be absolutely without utility, but it must have an idea behind it. It must have something in it which is inaccessible and which fills men with awe, but also with fear. It must be impersonal, because it is not the work of an individual; it is the symbol of a community united under a single ideal" [28]. This text leaves no doubts about the importance attached to considerations of "appearance" accumulated in the image of Nazi architectural façades. The façades destined again to tumble down, together with the ideology, which produced them, this time by the Second World War. 


\section{REFERENCES}

[1] Van de Velde H. Die Veränderte Grundlagen des Kunstgewerbes seit der Französischen Revolution // Van de Velde H. Zum neuen Stil. München, 1955. S. 141-142.

[2] Muthesius H. Kultur und Kunst. Nendeln / Lichtenstein, 1976. S. 14-15.

[3] H.Walden Schönheit! Schönheit! Der Fall Adolf Loos Konfrontationen. Schriften von und über Adolf Loos. Wien, 1988. S. 78.

[4] Behrens P. Alkohol und Kunst. Flensburg, 1905. S. 3.

[5] Van de Velde H. Das Streben nach einem neuen Stil, dessene Grundlagen auf vernünftigen, logischer Konzeption beruhen // Van de Velde H. Zum neuen Stil. München, 1955. S. 154.

[6] Cit.: Sternin G. O neoklassitsizme // Sud'by neoklassitsizma v XX veke (The Fate of Neo-Classicism in the 20th Century), Moscow, 1997, pp. 4-5.

[7] Rathenau W. Zur Mechanik des Geistes oder vom Reich der Seele 1913 // Rathenau W... S. 262.

[8] Osthaus K. E. Henry van de Velde: Leben und Schaffen des Künstlers. Hagen, 1920. S. 85.

[9] Cit. Windsor A. Peter Behrens. Architect and Designer, Whitney Library of Design, 1981, p. 121.

[10] Cit. Schwartz F. J. Von der Gründung zum „Typenstreit“/100 jahre Deutscher Werkbund 1907/2007. München, 2007. S. 49.

[11] Cit. Schwartz F. J. Von der Gründung zum „Typenstreit“/100 jahre Deutscher Werkbund 1907/2007... S. 49.

[12] The German for geniality; hereinafter translated from comments by A.N. Benois. See Alexander Nikolaievich Benois. Khudozhestvennye pis'ma 1908-1917: Rech newspaper, Petersburg. In three volumes. Eds. Iu.N. Podkopaeva, I.A. Zolotinkina, I.N. Krasik, Iu.L. Solonovich. Vol. 1, 1908-1910, St. Petersburg, 2006, p. 83.

[13] The German for the sense of duty.

[14] Benois A. N. Po Germanii (Across Germany) // Alexander Nikolaievich Benois ..., p. 83.

[15] Kirichenko E. I. Russkaia arkhitektura 1830-1910 godov (Russian architecture: 1830-1910s), Moscow, 1978, p. 363.

[16] Ibid.

[17] Haffner S. Von Bismark zu Hitler...S. 91-92.

[18] Naumann F. Werkbund und Weltwirtschaft. Vortrag, Werkbund Tagung 1914 // Zwischen Kunst und Industrie: Der Deutsche Werkbund. München, 1975. S. 115.

[19] Cit. Karl Ernst Osthaus. Leben und Werk. Recklinghausen, 1971. S. 89.

[20] Dann O. Natsii i natsionalizm v Germanii (Nation und Nationalismus in Deutschland 1770-1990, Nauka Publishers, 2003, p. 258.

[21] Mann T. "An Appeal to Reason" // The Weimar Republic Sourcebook, 1994, p. 153.

[22] Cit. Ikonnikov A.V. Zarubezhnaia arkhitektura. Ot "novoi arkhitektury" do postmoderna (Foreign Architecture. From "New" to Post-Moderne Architecture) Moscow, 1982, p. 53.

[23] Walter Gropius. The Scope of Total Architecture, Allen \& Unwin, 1956 , p. 23

[24] Behne A. "Kritik des Werkbundes"// Werkbundarchiv. Berlin, 1972. S. 118.

[25] Cit.: Schirren Matthias, Geist und Tat. Architektur und Städtebau der Avantgarde im Berlin der zwanziger Jahre // Berlin - Moskau. 19001950; Moscow, 1996, p. 212.

[26] Karl Ernst Osthaus: Leben und Werk... S. 475. Cit. Programs and Manifestoes of 20th-century Architecture, by Ulrich Conrads, 1970, pp. 57-8.

[27] Benjamin W. "Experience and Poverty" // Water Benjamin. Selected Writings. Vol. 2. 1927-1934. Belknap Press of Harvard University Press, 1999, p. 733-4.

[28] Tamms F. Das Grosse in der Baukunst // Durth W. Deutsche Architekten. Biografische Verflechtung 1900-1970... S. 242. 